\title{
Zabezpieczenie antykorozyjne instalacji napowierzchniowej i uzbrojenia wgłębnego odwiertów przeznaczonych do zatłaczania cieczy odpadowych i wody złożowej ${ }^{1}$
}

\begin{abstract}
W artykule przedstawiono wyniki badań mających na celu dobór odpowiedniego zabezpieczenia antykorozyjnego wyposażenia odwiertów przeznaczonych do zatłaczania cieczy odpadowych i wody złożowej. Przed wykonaniem badań: zostały wytypowane roztwory korozyjne na podstawie przeglądu rodzajów cieczy odpadowych i wód złożowych przeznaczonych do zatłaczania, określono odmiany wytrzymałościowe stali wchodzących w skład wyposażenia odwiertów do zatłaczania cieczy odpadowych, wytypowano inhibitory korozji oraz ustalono warunki prowadzenia testów. Badania obejmowały: ocenę wpływu zatłaczanych cieczy odpadowych na wyposażenie wgłębne i rurociągi napowierzchniowe, testy korozyjne próbek stalowych z użyciem poszczególnych inhibitorów korozji (porównanie skuteczności wytypowanych inhibitorów między sobą) oraz dobór optymalnej dawki najbardziej skutecznych inhibitorów.
\end{abstract}

Słowa kluczowe: szybkość korozji, inhibitory korozji, ochrona antykorozyjna.

\section{Anticorrosive well protection equipment designed for pumping wastes and reservoir waters}

\begin{abstract}
In this article are presented results of research to determine adequate corrosion protection for oil wells designed for pumping wastes and reservoir waters. The corrosion solutions were selected after reviewing the types of wastes and reservoir waters intended for pumping. The author chose corrosion inhibitors and the variations of steel characterized by different mechanical strength which comprises well equipment. Conditions of corrosion tests were determined as well. Then the author did estimation of the influence of pumping wastes, on surface and underground well equipment and performed tests for the effectiveness of corrosion inhibitors (comparison of their performance) on metal coupons, to determine the adequate quantity of the inhibitors for the best corrosion protection.
\end{abstract}

Key words: corrosion rate, corrosion inhibitors, anticorrosive protection.

\section{Wprowadzenie}

Celem przeprowadzonych badań był dobór odpowiedniego zabezpieczenia antykorozyjnego wyposażenia odwiertów dwóch kopalni $(\mathrm{K}, \mathrm{T})$ przeznaczonych do zatłaczania cieczy odpadowych i wody złożowej.

Praca składała się z dwóch etapów. Pierwszy z nich obejmował następujące zadania:
- wytypowanie roztworów korozyjnych do testów na podstawie przeglądu rodzajów cieczy odpadowych i wód złożowych przeznaczonych do zatłaczania,

- określenie odmian wytrzymałościowych stali wchodzących w skład wyposażenia odwiertów do zatłaczania cieczy odpadowych,

${ }^{1}$ Artykuł przedstawiony jako poster na Międzynarodowej Konferencji Naukowo-Technicznej GEOPETROL 2012. 
- wytypowanie inhibitorów korozji przeznaczonych do badań (z pomocą wiodących firm na rynku),

- ustalenie warunków testów (badania korozyjne w symulowanych warunkach rzeczywistych).

Powyższe punkty stanowiły wstępny zakres prac niezbędnych do zaplanowania dalszych działań, w szczególności właściwych testów korozyjnych mających na celu dobór skutecznego zabezpieczenia antykorozyjnego.
Drugi etap pracy obejmował następujące testy laboratoryjne:

- badania i ocenę wpływu zatłaczanych odpadów na wyposażenie wgłębne i rurociągi napowierzchniowe,

- testy korozyjne próbek stalowych z użyciem poszczególnych inhibitorów korozji (porównanie skuteczności wytypowanych inhibitorów między sobą),

- dobór optymalnej dawki w przypadku najbardziej skutecznych inhibitorów [4].

\section{Metodyka badań}

W kopalni T wytypowano dwa odwierty przeznaczone do zatłaczania cieczy odpadowych: T-21 i T-33. Natomiast w kopalni K do zatłaczania odpadów przeznaczono odwierty $\mathrm{K}-22$ i K-8.

\section{Wytypowanie roztworów korozyjnych}

Koncesja na podziemne składowanie w kopalni T obejmowała tylko wody złożowe. W momencie doboru ochrony do odwiertów zatłaczane były wody złożowe o pH około 6, solanki (mineralizacja około $100 \mathrm{~g} / \mathrm{dm}^{3} \mathrm{Cl}^{-}$) zawierające fenole. Ciecze odpadowe gromadzone są we wspólnym zbiorniku, z którego odprowadzane są do wyżej wymienionych odwiertów. Do badań zastosowano mieszaninę dwóch wód złożowych pobraną ze zbiornika, określaną w dalszej części opracowania jako woda złożowa T.

Koncesja na podziemne składowanie odpadów kopalni K obejmowała odpady powstające przy poszukiwaniu, wydobywaniu, fizycznej i chemicznej przeróbce rud oraz innych kopalin (wody złożowe pochodzące z różnych złóż węglowodorów, płuczki wiertnicze $\mathrm{i}$ inne odpady wiertnicze), a także odpady z przeróbki ropy naftowej, oczyszczania gazu ziemnego oraz pirolitycznej przeróbki węgla. W momencie doboru ochrony zatłaczane były wody złożowe z 7 ośrodków. Są to wody o pH około $6 \div 6,5$, solanki (mineralizacja około $60 \mathrm{~g} / \mathrm{dm}^{3} \mathrm{Cl}^{-}$) zawierające fenole, sporadycznie zdarzają się również ciecze poreakcyjne, np. po zabiegu kwasowania czy płukania odwiertów. Do badań pobrano ze zbiornika mieszaninę wód złożowych (określaną w dalszej części jako woda złożowa K) oraz jedną ciecz poreakcyjną po kwasowaniu odwiertu, jako odpad najbardziej niebezpieczny dla wyposażenia odwiertów. Ciecz poreakcyjna $\mathrm{w}$ dalszej części określana jest terminem ciecz po kwasowaniu $\mathrm{K}[1,3,4]$.

\section{Określenie gatunków stali poddawanych badaniom}

Odwiert T-21, o głębokości 1829 m, posiadał wymienioną instalację wgłębną wykonaną w większości ze stali gatun$\mathrm{ku} \mathrm{N-80,} \mathrm{natomiast} \mathrm{instalacja} \mathrm{napowierzchniowa,} \mathrm{długości}$ 302 m, zaplanowana była do wykonania z gatunku L-290 NB.
Odwiert T-33, o głębokości 2514 m, posiadał wymienioną instalację wgłębną wykonaną w większości ze stali gatunku J-55, natomiast instalacja napowierzchniowa, która powstała w latach 70. XX w. ze stali gatunku R-35, o długości $1698 \mathrm{~m}$, nie była przewidziana do wymiany.

Odwiert K-22, o głębokości 990 m, posiadał wymienioną instalację wgłębną, wykonaną w większości ze stali gatunku J-55, natomiast instalacja napowierzchniowa, o długości 1500 m, również po wymianie, wykonana była ze stali gatunku L-360 NB.

W odwiercie K-8, o głębokości 960 m, instalacja wgłębna przewidziana jest do wymiany, w której wykorzystana będzie stal gatunku J-55, natomiast instalacja napowierzchniowa, o długości 20 m, została wymieniona i do jej wykonania użyto stali gatunku L-360 NB.

Po określeniu odmian wytrzymałościowych stali wchodzących w skład wyposażenia odwiertów do zatłaczania odpadów ustalono, że testy korozyjne będą prowadzone dla gatunków stali N-80, J-55, L-290 NB, L-360 NB, R-35 [4].

\section{Wytypowanie inhibitorów}

Z prośbą o propozycje najbardziej odpowiednich inhibitorów do zabezpieczenia antykorozyjnego wyżej wymienionych odwiertów zwrócono się do pięciu firm działających na rynku. Większość z nich odpowiedziała pozytywnie na zapytanie i wytypowała inhibitory do badań, w wyniku czego w testach korozyjnych zastosowano środki oznaczone następującymi symbolami: C-4, W-1, T-0, T-2, H, K. Początkową dawkę inhibitorów dobrano na poziomie $0,2 \%$ objętościowo na podstawie własnych doświadczeń, konsultując je z zaleceniami producentów $[2,4]$.

\section{Ustalenie warunków prowadzenia testów}

Warunki prowadzenia testów korozyjnych ustalono na podstawie analizy warunków rzeczywistych panujących podczas zatłaczania cieczy odpadowych, przy czym uwzględniono fakt, że największe zagrożenie procesami korozyjnymi występuje w najwyższym przedziale temperaturowym. Temperatury $\mathrm{w}$ instalacji napowierzchniowej w zależności 
od pory roku znajdują się w przedziale od $-30^{\circ} \mathrm{C}$ do $+30^{\circ} \mathrm{C}$, natomiast $\mathrm{w}$ instalacji wgłębnej temperatura może dochodzić maksymalnie do $50^{\circ} \mathrm{C}$. Panujące ciśnienia są stosunkowo niskie i zawierają się w przedziale od 1,5 MPa do 6,5 MPa. Na podstawie wyżej przedstawionych danych ustalono, że testy będą prowadzone pod ciśnieniem atmosferycznym, w temperaturach $20^{\circ} \mathrm{C}$ dla gatunków stali L-290 NB, L-360 NB i R-35 oraz $50^{\circ} \mathrm{C}$ dla gatunków stali N-80 i J-55. Czas trwania jednego testu wynosił $720 \mathrm{~h}$ (30 dni).

Badania przeprowadzono zgodnie z normami: ASTM G1-03, ASTM G31-72 (2004), ASTM G111-97 (2006), NACE Standard TM0169-2000, PN-76/H-04601, PN-76/H-04602, PN-78/H-04610 [5-11]. Test polegał na umieszczeniu trzech kuponów wykonanych z określonego gatunku stali w każdym badanym medium korozyjnym i utrzymaniu ustalonych warunków ciśnienia i temperatury przez cały okres trwania badania. W celu wygładzenia i ujednolicenia powierzchnię próbki przed testem szlifowano na papierach ściernych, czyszczono, odtłuszczano, suszono i ważono z dokładnością 0,0001 g. Po zakończeniu badań kupony odtłuszczono, oczyszczono chemicznie oraz zważono z dokładnością 0,0001 g. Szybkość korozji obliczono na podstawie ubytków masy. W wyżej wymienionych warunkach należy spodziewać się przede wszystkim wystąpienia korozji równomiernej, możliwe jest również pojawienie się korozji wżerowej.

\section{Badania laboratoryjne}

W początkowym etapie realizacji pracy przeprowadzone zostały badania mające na celu ocenę wpływu zatłaczanych cieczy odpadowych na wyposażenie wgłębne odwiertów i rurociągi doprowadzające. Wyniki testów przedstawiono na rysunku 1.

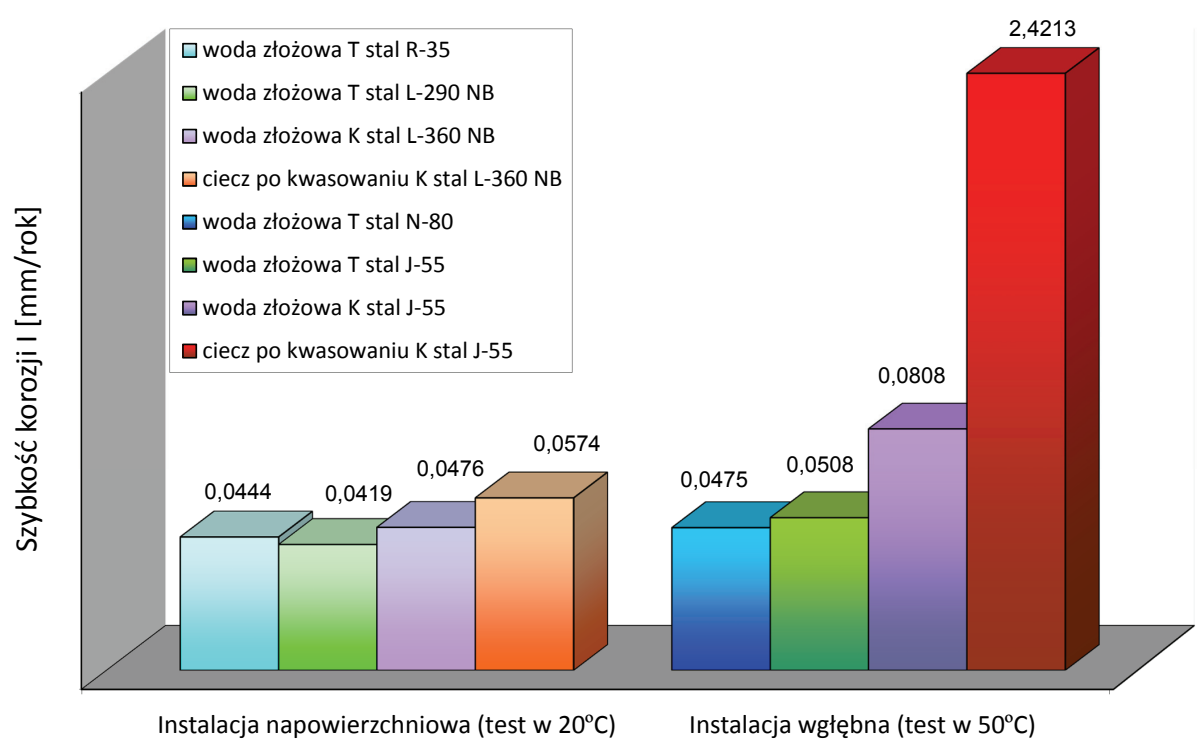

Rys. 1. Szybkość korozji poszczególnych gatunków stali wyposażenia napowierzchniowego i wgłębnego odwiertów kopalni T i K korozji w temperaturze $50^{\circ} \mathrm{C}$ jest około 40 -krotnie wyższe niż w wodach złożowych i wynosi $2,4 \mathrm{~mm} /$ rok [4].

Przy porównaniu odporności korozyjnej stali między sobą nieznacznie lepsze wyniki zanotowano dla odmian L-290 NB oraz N-80. Rezultaty przeprowadzonych testów wykazały, że badane ciecze odpadowe są środowiskami korozyjnymi stwarzającymi co najmniej średnie zagrożenie dla wyposażenia odwiertów i konieczne jest zastosowanie ochrony inhibitorowej.

W następnej kolejności wykonano testy skuteczności ochronnej poszczególnych inhibitorów korozji. Badania początkowe pozwoliły na wyłonienie inhibitorów zapewniających najlepszą ochronę wyposażenia odwiertów przeznaczonych do zatłaczania cieczy odpadowych.

Przeprowadzono także badania w wodzie destylowanej, mające być odnośnikiem poziomu szybkości korozji w ocenie skuteczności jej zapobiegania przez dobierane inhibitory. Rezultaty przykładowych testów ko-
Szybkość korozji gatunków stali, z których wykonano instalacje napowierzchniowe odwiertów, w wodach złożowych $\mathrm{w} 20^{\circ} \mathrm{C}$ wynosi około $0,045 \mathrm{~mm} /$ rok. W przypadku cieczy kwasującej szybkość korozji zbliża się do wartości $0,06 \mathrm{~mm} /$ rok, natomiast szybkość korozji stali instalacji wgłębnej odwiertów kopalni $\mathrm{T}$ w wodzie złożowej w $50^{\circ} \mathrm{C}$ wynosi około $0,05 \mathrm{~mm} /$ rok. W wodzie złożowej K korozja badanej stali postępuje szybciej, bo w tempie $0,08 \mathrm{~mm} /$ rok. Najbardziej korozyjnym środowiskiem okazała się, zgodnie z przewidywaniami, ciecz po kwasowaniu, w której tempo rozyjnych przedstawiono na rysunkach 2 i 5 .

Na podstawie wyników testów początkowych dokonano porównania ochrony antykorozyjnej poszczególnych inhibitorów korozji i wytypowano najbardziej skuteczne [4].

Dla ochrony uzbrojenia odwiertów przeznaczonych do zatłaczania cieczy odpadowych w kopalni T środkami zapewniającymi największą ochronę okazały się inhibitory W-1 oraz H. Spośród wszystkich testowanych środków z nimi uzyskiwano najlepsze wyniki zarówno w przypadku instalacji napowierzchniowej (test $\mathrm{w} 20^{\circ} \mathrm{C}$ ), jak i wgłębnej (test $\mathrm{w} 50^{\circ} \mathrm{C}$ ). 


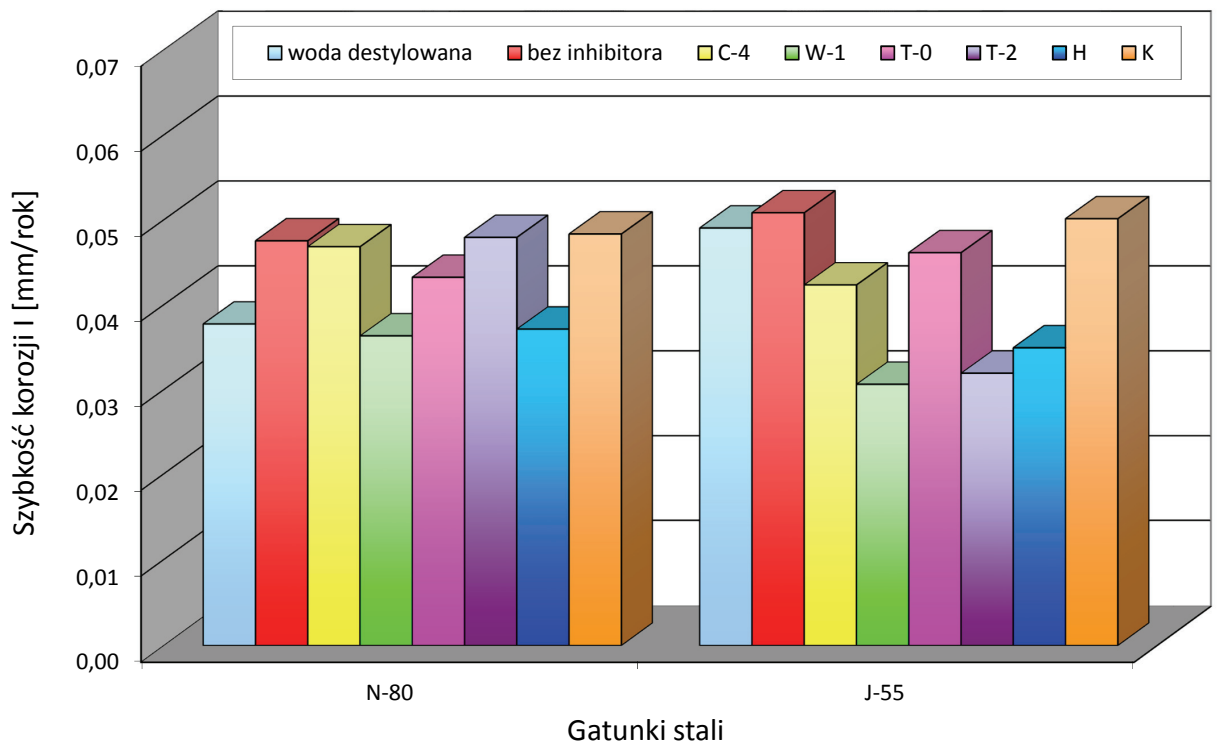

Rys. 2. Szybkość korozji gatunków stali N-80 i J-55 w środowisku wody złożowej T $\mathrm{z}$ użyciem 6 inhibitorów korozji w temperaturze $50^{\circ} \mathrm{C}$
Inhibitory $\mathrm{W}-1, \mathrm{H}, \mathrm{C}-4, \mathrm{~T}-0$ poddano dalszym testom, mającym na celu dobór najmniejszej najbardziej skutecznej dawki do zastosowania. Oprócz dawki 0,2\% obj. stosowanej w badaniach wstępnych użyto dawki $0,3 \%$ i $0,4 \%$ obj. Wyniki przykładowych testów doboru dawki przedstawiono na rysunku 5 .

Testy doboru objętości środka pozwoliły na wytypowanie najbardziej skutecznego stężenia inhibitorów poddanych badaniom. Umożliwiły także ostateczny wybór najlepszego inhibitora do ochrony instalacji odwiertów przeznaczonych do zatłaczania cieczy odpadowych.
Szybkości korozji badanych gatunków stali z zastosowaniem inhibitorów W-1 i H wynosiły około $0,0150 \mathrm{~mm} /$ rok dla $20^{\circ} \mathrm{C}$ i około $0,0420 \mathrm{~mm} /$ rok dla $50^{\circ} \mathrm{C}$. W przypadku stali instalacji napowierzchniowej były to wartości dwukrotnie mniejsze niż w roztworach testowych bez zastosowania ochrony antykorozyjnej. Natomiast dla stali instalacji wgłębnej szybkość korozji w wyniku użycia inhibitorów zmniejszyła się o około 30\%. Korozja stali przy zastosowaniu najlepszych inhibitorów postępowała także nieznacznie wolniej niż w kontrolnych testach w wodzie destylowanej. Ogólnie skuteczność ochrony antykorozyjnej poszczególnych inhibitorów nie różniła się znacząco. Rozbieżności wynosiły około $0,01 \mathrm{~mm} /$ rok [4].

Do ochrony uzbrojenia odwiertów przeznaczonych do zatłaczania odpadów w kopalni K najlepsze okazały się inhibitory C-4, W-1, T-0. Wszystkie badane środki w większości przypadków osiągają porównywalne wyniki, jednak dla rur wydobywczych (test w $50^{\circ} \mathrm{C}$ ) oraz w cieczy kwasującej wytypowane inhibitory zapewniają lepszą ochronę od pozostałych.

Szybkość korozji badanych gatunków stali z zastosowaniem C-4, W-1 i T-0 wynosiła około 0,02 $\div 0,04 \mathrm{~mm} /$ rok w wodzie złożowej oraz od $0,05 \mathrm{~mm} / \operatorname{rok}\left(20^{\circ} \mathrm{C}\right)$ do około $0,6 \mathrm{~mm} / \mathrm{rok}$ $\left(50^{\circ} \mathrm{C}\right) \mathrm{w}$ cieczy poreakcyjnej po kwasowaniu. Były to wartości kilkakrotnie mniejsze niż w roztworach testowych bez wykorzystania ochrony antykorozyjnej. Szybkość korozji stali z zastosowaniem badanych inhibitorów była także w większości przypadków porównywalna z szybkością korozji w kontrolnym teście w wodzie destylowanej [4].

Korozja kuponów stalowych poddanych badaniom miała charakter równomierny, nie zaobserwowano korozji wżerowej. Zdjęcia przykładowych próbek przedstawiają rysunki 3 i 4.

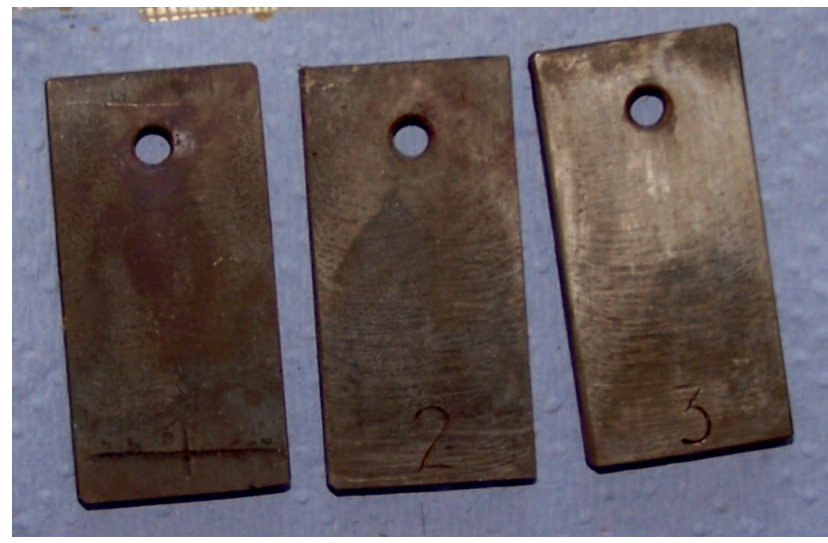

Rys. 3. Zdjęcie próbek stali gatunku J-55 poddanych działaniu cieczy po kwasowaniu $\mathrm{K}$ bez dodatku inhibitora $\mathrm{w} 50^{\circ} \mathrm{C}$

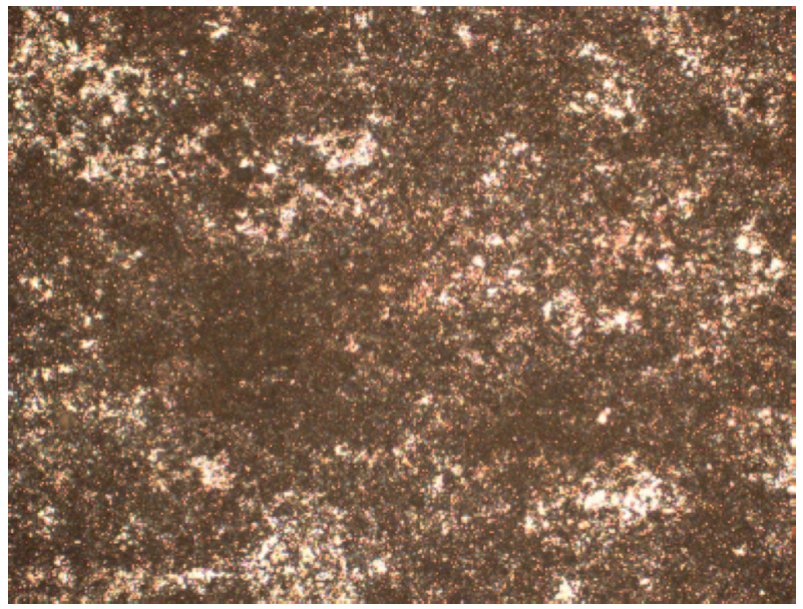

Rys. 4. Zdjęcie mikroskopowe (powiększenie około $50 \times$ ) powierzchni próbki stali gatunku J-55 poddanej działaniu cieczy poreakcyjnej po kwasowaniu $\mathrm{K}$ bez dodatku inhibitora $\mathrm{w} 50^{\circ} \mathrm{C}$

Dawki inhibitorów W-1 i H, wstępnie wybranych do zastosowania w kopalni T, we wszystkich przypadkach są równe $0,4 \%$. 
Zwiększenie dawki inhibitora z 0,2\% (użyta w testach wstępnych) do $0,4 \%$ poprawia skuteczność ochrony antykorozyjnej o $30 \%$, a niekiedy nawet o $60 \%$. Do zastosowania w kopalni T najbardziej skuteczny jest inhibitor $\mathrm{H}$, szczególnie w przypadku rur napowierzchniowych, gdyż zapewnia 5-krotnie lepszą ochronę niż W-1. Szybkość korozji stali instalacji napowierzchniowej przy dawce $0,4 \%$ inhibitora $\mathrm{H}$ wynosiła około 0,003 mm/rok. Jest to wartość 14-krotnie mniejsza od szybkości korozji bez zastosowania ochrony inhibitorowej [4].

Natomiast $\mathrm{w}$ instalacji wgłębnej obydwa inhibitory zapewniają porównywalną ochronę. Szybkość korozji stali instalacji wgłębnych przy dawce inhibitora $0,4 \%$ wynosi około $0,025 \mathrm{~mm} / \mathrm{rok}$. To wartość ponad dwukrotnie mniejsza niż bez zastosowania ochrony inhibitorowej. zwiększenia stężenia do $0,4 \%$ zmniejszyła się o $20 \%$, a niekiedy o $60 \%$. Najbardziej skutecznym inhibitorem jest C-4, co szczególnie uwidacznia się w przypadku rur w środowisku cieczy poreakcyjnej po kwasowaniu. W środowisku wody złożowej wszystkie badane inhibitory zapewniają porównywalną ochronę antykorozyjną instalacji. Szybkość korozji stali instalacji napowierzchniowej przy dawce inhibitora C-4 równej $0,4 \%$ wynosi od około $0,012 \mathrm{~mm} /$ rok w wodzie złożowej do $0,038 \mathrm{~mm} /$ rok w cieczy poreakcyjnej po kwasowaniu. Jest to wartość odpowiednio 4- i 2-krotnie mniejsza niż bez zastosowania ochrony inhibitorowej. W przypadku stali instalacji wgłębnej szybkość korozji w wodzie złożowej po zastosowaniu wszystkich 3 inhibitorów jest zbliżona i wynosi około $0,03 \mathrm{~mm} /$ rok (prawie 3-krotnie mniej niż bez ochrony inhibitorowej). Natomiast w środowisku cieczy kwasującej zdecydowanie najlepsze wyniki osiągnięto dzięki środkowi C-4. Szybkość korozji wynosi w tym przypadku około $0,1 \mathrm{~mm} / \mathrm{rok}$ i niewiele różni się dla poszczególnych dawek. Wynik ten jest ponad 20-krotnie lepszy niż bez ochrony inhibitorowej.

Ogólnie środowisko pracy instalacji odwiertów przeznaczonych do zatłaczania cieczy odpadowych jest bardziej korozyjne w kopalni K, co jest zrozumiałe z racji faktu, iż w kopalni $\mathrm{T}$ zatłaczane są tylko wody złożowe [4].

Wytypowane inhibitory powinny być dozowane (dawka $0,4 \%$ w stosunku do ilości zatłaczanych odpadów) do zbiorników „czystych” (po przejściu odpadów przez osadnik i filtry),

Rys. 5. Szybkość korozji stali gatunku L-360 NB w środowisku wody złożowej K i cieczy poreakcyjnej po kwasowaniu $\mathrm{K}$ z użyciem inhibitorów korozji C-4, W-1, T-0 w różnych dawkach $\mathrm{w}$ temperaturze $20^{\circ} \mathrm{C}$

W przypadku inhibitorów C-4, W-1 i T-0, wybranych do dalszych testów z przeznaczeniem do zastosowania w kopalni K, dawką najbardziej skuteczną również okazało się stężenie $0,4 \%$. Szybkość korozji badanych stali w wyniku w sposób zapewniający wymieszanie i zapobiegający osadzaniu się inhibitora na dnie, lub bezpośrednio za tym zbiornikiem, na wyjściu cieczy odpadowych do instalacji napowierzchniowych.

\section{Wnioski}

1. Wyniki przeprowadzonych testów wykazały, że badane ciecze odpadowe są środowiskami korozyjnymi stwarzającymi co najmniej średnie zagrożenie dla wyposażenia odwiertów, a w związku z tym konieczne jest zastosowanie ochrony inhibitorowej.

2. Środowisko pracy instalacji odwiertów przeznaczonych do zatłaczania cieczy odpadowych jest bardziej korozyjne w kopalni K, co jest zrozumiałe z racji faktu, iż w kopalni $\mathrm{T}$ zatłaczane są tylko wody złożowe.
3. Szybkość korozji gatunków stali, z których wykonane są instalacje napowierzchniowe, bez wykorzystania ochrony inhibitorowej wynosi około $0,0450 \mathrm{~mm} /$ rok w wodach złożowych oraz $0,08 \mathrm{~mm} /$ rok w cieczy po kwasowaniu.

4. Szybkość korozji gatunków stali, z których wykonane sa instalacje wgłębne bez wykorzystania ochrony inhibitorowej wynosi około $0,0500 \mathrm{~mm} /$ rok w wodach złożowych oraz $2,4 \mathrm{~mm} /$ rok w cieczy po kwasowaniu. 
5. Inhibitorem wytypowanym do zastosowania w kopalni T jest środek H w dawce 0,4\% w stosunku do ilości zatłaczanych cieczy odpadowych.

6. Użycie środka H w dawce $0,4 \%$ obniża szybkość korozji do wartości około $0,003 \mathrm{~mm} /$ rok w instalacji napowierzchniowej i do $0,025 \mathrm{~mm} /$ rok w instalacji wgłębnej.

7. Inhibitorem wytypowanym do zastosowania w kopalni $\mathrm{K}$ jest C-1 w dawce $0,4 \%$ w stosunku do ilości zatłaczanych cieczy odpadowych.

8. Użycie środka C-1 w dawce $0,4 \%$ obniża szybkość korozji w wodzie złożowej do wartości około $0,012 \mathrm{~mm} / \mathrm{rok}$ w instalacji napowierzchniowej i do około $0,03 \mathrm{~mm} / \mathrm{rok}$ w instalacji wgłębnej.
9. Użycie środka C-1 w dawce $0,4 \%$ obniża szybkość korozji w cieczy po kwasowaniu do $0,0380 \mathrm{~mm} / \mathrm{rok} \mathrm{w}$ instalacji napowierzchniowej i do około $0,1000 \mathrm{~mm} / \mathrm{rok}$ w instalacji wgłębnej.

10. Korozja kuponów stalowych poddanych badaniom miała charakter równomierny, nie zaobserwowano korozji wżerowej.

11. Wytypowane inhibitory powinny być dozowane do zbiorników „czystych” (po przejściu odpadów przez osadnik i filtry), w sposób zapewniający wymieszanie i zapobiegający osadzaniu się inhibitora na dnie, lub bezpośrednio za tym zbiornikiem, na wyjściu cieczy odpadowych do instalacji napowierzchniowych.

Prosimy cytować jako: Nafta-Gaz 2016, nr 11, s. 939-944, DOI: 10.18668/NG.2016.11.07

Artykuł nadesłano do Redakcji 6.07.2016 r. Zatwierdzono do druku 18.10.2016 r.

Artykuł powstał na podstawie pracy badawczej pt. Zabezpieczenie antykorozyjne instalacji i uzbrojenia wgłębnego odwiertów przeznaczonych do zatłaczania odpadów $i$ wody złożowej - praca INiG - PIB na zlecenie PGNiG SA, nr umowy 266/DOK/2007, nr zlecenia 677/DOK.

\section{Literatura}

[1] Krasińska A., Król A.: Ocena szkodliwości odpadów wydobywczych w świetle obowiazujacych wymagań prawnych na przyktadzie odpadów wytwarzanych podczas konwencjonalnego poszukiwania węglowodorów. Nafta-Gaz 2012, nr 12, s. $1170-1175$.

[2] Stachowicz A.: Inhibitorowa ochrona antykorozyjna dla urzadzeń eksploatacyjnych i przesyłowych kopalni ropy naftowej i gazu ziemnego. Nafta-Gaz 2010, nr 3, s. 197-202.

[3] Stachowicz A.: Korozja wyposażenia wgłębnego oraz skuteczność ochrony inhibitorowej podczas kwasowania odwiertów. Nafta-Gaz 2009, nr 6, s. 469-473.

[4] Stachowicz A.: Zabezpieczenie antykorozyjne instalacji i uzbrojenia wgłębnego odwiertów przeznaczonych do zatłaczania odpadów $i$ wody złożowej. Praca INiG - PIB na zlecenie PGNiG SA, Krosno 2008.

\section{Akty prawne i normatywne}

[5] ASTM G1-03 Standard Practice for Preparing, Cleaning and Evaluating Corrosion Test Specimens.

[6] ASTM G111-97 (2006) Standard Guide for Corrosion Tests in High Temperature or High Pressure Environment, or Both.

[7] ASTM G31-72 (2004) Standard Practice for Laboratory Immersion Corrosion Testing of Metals.

[8] NACE Standard TM0169-2000 Item No. 21200 Laboratory Corrosion Testing of Metals.

[9] PN-76/H-04601 Korozja metali. Badanie laboratoryjne w cieczach i roztworach $w$ temperaturze otoczenia.

[10] PN-76/H-04602 Korozja metali. Badanie laboratoryjne w cieczach i roztworach w temperaturze podwyższonej.

[11] PN-78/H-04610 Korozja metali. Metody oceny badań korozyjnych.

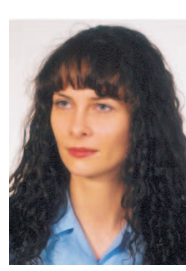

Mgr inż. Agnieszka STACHOWICZ

Starszy specjalista badawczo-techniczny w Zakładzie Symulacji Wydobycia Węglowodorów. Instytut Nafty i Gazu - Państwowy Instytut Badawczy ul. Lubicz 25 A

31-503 Kraków

E-mail: agnieszka.stachowicz@inig.pl 